\title{
Evaluation of Wound Healing Effect of Eel Mucus Ointment (Belutidine) in Mice by Incision Model
}

\author{
Muhammad Thorieq Ali*, Muhammad Fadli Ashari, \\ Santika Puji Rahayu Wijaya, Endang Lestari and Rina Wijayanti
}

Faculty of Medicine, Research Institute, Department of Pharmacy, Universitas Islam Sultan Agung, Indonesia; thorieq1097@gmail.com

\begin{abstract}
Background: It has been reported by the Ministry of Health that the prevalence of wounded and worsening events is increasing in Indonesia. This situation requires more intensive attention. Eel mucus has been an alternative treatment of wounds in some parts of Indonesian society since ancient times. Aim and Objectives: To explore the effectiveness of eel mucus ointment as a natural wound healing product. Material and Methods: This experimental study used 45 mice divided into 3 groups; 15 mice in each group. All mice were aseptically wounded $1.5 \mathrm{~cm}$ on their anterior region of back skin using a sterile scalpel, and then treated with placebo, povidone iodine ointment, and with eel mucous ointment (Belutidine). On the third, sixth and ninth day, the mice were sacrificed. Data on wound length were taken on $9^{\text {th }}$ day. Microscopic data of histologic slides collected were: number of neutrophil, mono-nuclear, neo-vascular and fibrosis cells. Data were analyzed using statistical analysis. Results: There was a significant difference in wound length between the groups $(p=0.008)$. The number of mono-nuclear cells on the third day was different significantly among the groups $(p=0.008)$. There was no significant difference of the overall observed cells on day 6 and there was a difference in mean number of neutrophils and fibrosis on day nine $(p<0.05)$. On day nine, the group treated with eel mucus ointment had the highest number of mean of neo-vascular and fibrosis cells. Conclusion: Eel mucous ointment is effective for wound healing.
\end{abstract}

Keywords: Eel Mucus Ointment, Fibrosis Cells, Mono-nuclear, Neo-vascular, Neutrophil, Wound Healing

\section{Introduction}

A wound is a laceration or break of the skin surface caused by thermal or physical injury ${ }^{1}$. Wounds due to sharp objects can become port de entry of infectious agents into the body. This condition can cause longer healing process. In Indonesia, it was reported that the prevalence of wounds caused by sharp objects is $7.3 \%$ higher than wounds caused by burns $(0.7 \%)^{2}$. Commonly, people use povidone iodine $10 \%$ for wound healing. In turn, the medication cannot be applied for a long time because it has side effects such as allergic reaction, toxic to fibroblast skin, and causing skin irritation during healing process $^{3}$. Efforts should be made to reduce the incidence of wound worsening caused by sharp objects, such as by utilizing natural materials provided by environment for wound treatment ${ }^{4}$.

The use of natural materials for the treatment of various skin conditions has been popular since ancient time. Some of these natural medicines are considered

*Author for correspondence 
to have therapeutic potential and should therefore be investigated for use in the advancement of products in the treatment of skin burns and wounds. ${ }^{5-7}$

In some areas in Indonesia, eel mucus is used as a traditional medication for wound healing. The treatment has advantages as eel mucus can be easily obtained in all seasons. This is contrary to the public opinion that the eels can only be consumed as food. The use of eel mucus as a medicine is potential to increase the utilization of eels other than as a food only. ${ }^{8}$

Research on the use of mucus as a wound remedy has been done before. There are reports about the use of snail mucus (Achatina fulica) for wound healing, and the results showed that snail mucus contained glycoprotein and heparin sulphate which have an important role for angiogenesis in cuts and also on burns ${ }^{5,9}$. Research using Japanese eel mucus (Anguilla japonica) also reported somewhat similar contents those were glycoprotein, lectin, hemagglutinin and hemolysin which also act in angiogenesis and as antimicrobial factors. Javanese eel (Monopterus albus) which physically resembles Japanese eel (Anguilla japonica) also contains glycoproteins but the proteins that play a role in angiogenesis are not yet known ${ }^{10}$. Considering that, the Javanese eel mucus might be a potential wound healing substance, just like other eel mucus. The problem is that pure eel mucus will dilute if it is left long, which might reduce its potential benefit as wound healing. Over time this mucus will also rot and produce an unpleasant odour. The circumstance makes the use of pure eel mucus inefficient. Therefore, it is necessary to develop a method so that the eel mucus can be stored for a long period and used at any time. One possible method is to make eel mucus ointment. Ointment is selected as the potential method, as the appropriate and effective topical formulation of ointment is reported to reduce and prevent infection of the wound ${ }^{11}$. It is expected that in this type of ointment, eel mucus can be stored longer as a drug preparation and used in a practical, effective and economical way. This study aims to examine the effectiveness of eel mucous ointment for wound healing.

\section{Material and Methods}

This study was an experimental study, to examine the effect of eel mucus ointment on healing of wounds, based on the histopathological analysis of the wounds. This study was approved by the Bioethics Committee for Medical/ Health Research Faculty of Medicine Islamic University of Sultan Agung Semarang (Letter No. 174/ IV/2017/KomisiBioetik).

\subsection{Eel Mucus Ointment Formulation}

Eel mucus was obtained from the eel body by scrubbing eel skin that has been clean and washed to obtain the amount of mucosa needed. The eels were put back to the water to restore the surface of the skin right after being scrubbed. The basic ingredient of ointment used was hydrocarbon ointment based, consisting of $64.1 \%$ Vaseline, $10 \%$ adeps lanae (lanolin), 0,1\% methyl paraben and 25\% Javanese eel (Monopterus albus) mucus. Vaseline and adeps lanae were mixed in a $90^{\circ} \mathrm{C}$ pre-heated saucer until they become a homogeneous formulation. Then the eel mucus and methyl paraben were added and mixed. The mixture was stirred, well mixed, cooled and was stored in the refrigerator.

\subsection{Grouping of Mice and Treatment}

The population of this study was mice aged between 2-2.5 months, of $250 \mathrm{~g}$ weight and had no anatomical abnormalities that were treated in the animal laboratory of Biology Department, Faculty of Medicine Universitas Islam Sultan Agung. The study used 45 mice. They were aseptically wounded $1.5 \mathrm{~cm}$ on their anterior region of back skin using a sterile scalpel. The mice were given intramuscular anesthesia using ketamine (dose 40 $\mathrm{mg} / \mathrm{kg} \mathrm{BW}$ ) before wounding the mice, to ensure that they do not feel pain when they were given an incision. The cut is made by pressing the scalpel with a depth of $0.3 \mathrm{~cm}$ and with $1.5 \mathrm{~cm}$ of length ${ }^{12,13}$. Furthermore, the mice were randomly divided into three groups; 15 mice in each group. Each group received the following interventions: Group I was treated with placebo (ointment of Vaseline only), Group II was the control group treated with povidone iodine ointment, and Group III was the treatment group, treated with eel mucus ointment named as "Belutidine". The name of the Belutidine has been taken from the name of the eel (Belut is the Indonesian name of eel). The use of Vaseline for placebo was to make sure that excision model also tried for the same activity with the treatment 
group. The treatment was done twice daily, at 07.00 am and at $4.00 \mathrm{pm}$. All of the mice received standard feed during the treatment, and they were grouped in cages according to the treatment given.

\subsection{Data Collecting Technique}

After treatment, five mice from each group were sacrificed on day 3, day 6 and day 9. Therefore, 15 mice from three groups were sacrificed on each mentioned day. The skins with the wound were taken of size $2 \times 2 \mathrm{~cm}$ wide and then fixed with $10 \%$ Neutral Buffered Formalin (NBF) solution to make histopathology slides. The slides were prepared by an expert in the anatomical pathology laboratory of Medical Faculty of Universitas Islam Sultan Agung. The data collected from the microscopic observations of histologic preparations on the $3^{\text {rd }}, 6^{\text {th }}$ and $9^{\text {th }}$ days were: the number of inflammatory cells (neutrophils and mono-nuclear), the number of neovascular, and the number of fibrosis cells.

\subsection{Data Analysis}

The mean difference of wound length among groups on $9^{\text {th }}$ day was evaluated Kruskal wallis statistical test, followed by Mann Whitney test. The mean difference of neutrophil, mono-nuclear, neo-vascular and fibrosis cells among groups were analyzed using One Way Anova test, followed by post hoc test, for normally distributed data and using Kruskal Wallis test and Mann Whitney test were utilized to test the difference of median of not normally distributed data.

\section{Results}

The data obtained from this study were the findings of macroscopic and microscopic observation of wounds, taken on day 3, day 6 , day 9 of treatment. The cells were observed from five sites of each slide. The macroscopic observation data was the length of the scarring of the groups on the $9^{\text {th }}$ day of treatment. Figure 1 describes that on day 9, the placebo group had the longest wound length; that was $0.74 \mathrm{~cm}$, while the eel mucus ointment group (Belutidine) had the shortest wound length; that was $0.28 \mathrm{~cm}$. The result of Saphiro Wilk analysis indicated that data o Placebo group (Vaseline ointment), povidone iodine group and ell mucus ointment group were not normally distributed and homogenous $(\mathrm{p}=0.105$, $0.000,0.000$, respectively) therefore Kuskal Wallis non parametric test was used to evaluate the difference of the median among groups. The result of Kruskal Wallis test showed that there was a significant difference in the median length of wound in all three groups. Mann Whitney test results showed that there was a median difference in wound length between the placebo group and the eel mucus ointment group (Belutidine) and there was a significant difference in the median wound length between the povidone iodine group and the eel mucus ointment group ( $\mathrm{p}=0.007$ and 0.005 respectively) (Figure 1).

The Kruskal Wallis test result indicated that on day 3 , only mononuclear cell data that were significantly different among groups, with p value of 0.008 (Table 1). Meanwhile, Mann Whitney test results indicated that there was a significant difference between the median of mononuclear cells of the placebo group and the median of mononuclear cells of povidone iodine group, as well as a significant difference between the median of mononuclear cells of the povidone iodine group and the median of that of the eel mucus ointment group; $\mathrm{p}=0.008$ and $\mathrm{p}=0.009$ respectively (Figure 2 ).

On day 6, neutrophil, mono-nuclear cells, neovascular cells, and fibrosis increased their amount compared to those of on day 3. The result of Saphiro Wilk analysis indicated that all data were normally distributed and homogenous; therefore, to evaluate the hypotheses

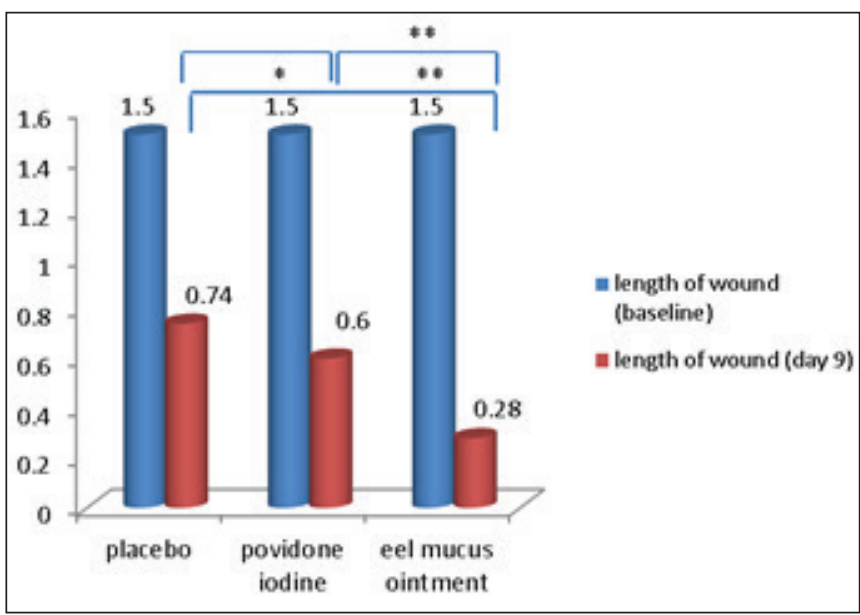

Fig. 1. Mean of Wound Length on Day 9 $\left[{ }^{*} p>0.05 ;{ }^{* *} p<0.05\right]$. 
Tabel 1: Median of Histopathologic Data of Wound on Day 3

\begin{tabular}{|c|c|c|c|c|c|c|c|c|}
\hline \multirow{3}{*}{$\begin{array}{l}\text { Group (N samples } \\
\text { evaluated on day } 3 \text { ) }\end{array}$} & \multicolumn{8}{|c|}{ Mean } \\
\hline & \multicolumn{2}{|c|}{ Neutrophil } & \multicolumn{2}{|c|}{ Mononuclear } & \multicolumn{2}{|c|}{ Neo-vascular } & \multicolumn{2}{|c|}{ Fibrosis } \\
\hline & Mean & SD & Mean & SD & Mean & SD & Mean & SD \\
\hline Placebo (Vaseline ointment) $(\mathrm{N}=5)$ & 24.6 & 10.9 & 139.2 & 15.4 & 4.6 & 5.4 & 3.2 & 2.2 \\
\hline Povidone iodine $(\mathrm{N}=5)$ & 37.2 & 16.8 & 255 & 43.8 & 3.6 & 4.8 & 24.4 & 31.5 \\
\hline Eel mucus ointment (Belutidine) $(\mathrm{N}=5)$ & 39.0 & 26.4 & 111.8 & 59.7 & 4.8 & 2.1 & 7.4 & 1.9 \\
\hline p Kruskal Wallis Test & 0.452 & & $0.008^{*}$ & & 0.348 & & 0.273 & \\
\hline
\end{tabular}

* significantly different based on Kruskal Wallis test

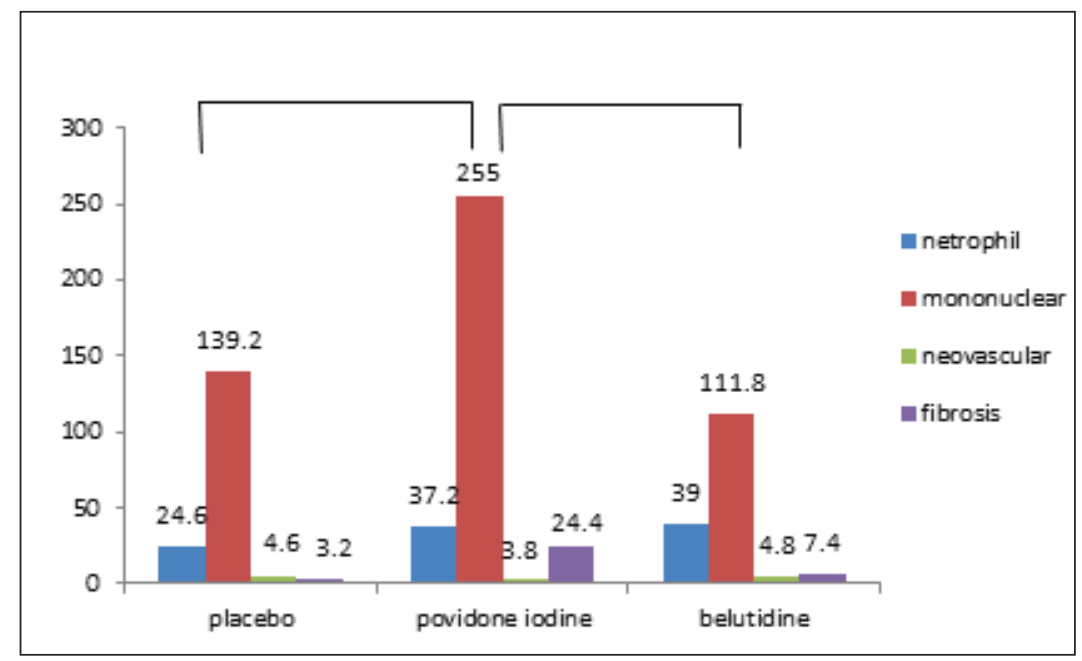

Fig. 2. Mean of Neutrophil, Mono-nuclear Cells, Neo-vascular Cells, and Fibrosis of Day 3.

${ }^{* *} \mathrm{p}<0.05$, significantly different based on Mann Whitney test]

of mean difference among the group, One Way Anova test was applied.

Table 2 indicated that at $6^{\text {th }}$ day, there wes significant mean difference of evaluated cells to the other groups'; $p>0.05$. From the results, it can be inferred that there were no significant difference of inflammation and proliferation process on $6^{\text {th }}$ day of treatment.

On the $9^{\text {th }}$ day, mean of neutrophils tends to decrease compared to those of the $6^{\text {th }}$ day, but the mean of fibrosis of that group tends to be higher than those of the $6^{\text {th }}$ day.

Tabel 2: Mean of Histopathologic Data of Wounds on Day 6

\begin{tabular}{|c|c|c|c|c|c|c|c|c|}
\hline \multirow{3}{*}{$\begin{array}{l}\text { Groups ( } \mathrm{N} \text { samples } \\
\text { evaluated on day } 6 \text { ) }\end{array}$} & \multicolumn{8}{|c|}{ Mean } \\
\hline & \multicolumn{2}{|c|}{ Neutrophil } & \multicolumn{2}{|c|}{ Mononuclear } & \multicolumn{2}{|c|}{ Neo-vascular } & \multicolumn{2}{|c|}{ Fibrosis } \\
\hline & Mean & SD & Mean & SD & Mean & SD & Mean & SD \\
\hline Placebo (Vaseline ointment) $(\mathrm{N}=5)$ & 18.4 & 23.2 & 123.2 & 90.5 & 94.8 & 32.5 & 67.0 & 54.2 \\
\hline Povidone iodine $(\mathrm{N}=5)$ & 9.6 & 8.5 & 171.2 & 89.3 & 100.4 & 73 & 103.2 & 53.3 \\
\hline Eel mucus ointment (Belutidine) $(\mathrm{N}=5)$ & 24.2 & 13.4 & 122 & 54.9 & 121 & 74.3 & 60 & 26.6 \\
\hline One Way Anova & 0.390 & & 0.556 & & 0.660 & & 0.324 & \\
\hline
\end{tabular}


The povidone iodine group had the largest number of mononuclear cells, averaging 185.6 cells, indicating that within the $9^{\text {th }}$ day of treatment, inflammation was still occurring in the group. Meanwhile, the group treated with eel mucus ointment (Belutidine) had the highest mean of neo-vascular and fibrosis cells; those were 185.2 and 301.4 cells respectively, indicating that this group had a faster proliferation process compared to the other counterparts.

The data of neutrophil, mono-nuclear cells, neovascular cells, and fibrosis were not normally distributed; therefore, Kruskal Wallis test was applied to evaluate the median difference among. The results indicated that there were significant differences of median of neutrophil and fibrosis cell among groups ( $\mathrm{p}=0.041$ and 0.009 respectively) (Table 3 ).
Mann Whitney test revealed that there was significant difference of neutrophil cells' median of placebo and povidone iodine group $(\mathrm{p}=0.032)$. In addition, there was a significant difference between the median of fibrosis cells of the placebo group and that of the eel mucus ointment (Belutidine) group, as well as between the median of fibrosis cells of povidone iodine group and that of eel mucus ointment (Belutidine) group $(\mathrm{p}=0.008$ and 0.008 , respectively) (Figure 4 ).

Histopathologic test of images of the placebo, povidone iodine and eel mucus ointment (Belutidine) groups on the $9^{\text {th }}$ day showed that the eel mucus ointment group had the highest number of fibrosis compared to the other groups. Neutrophil cells could not be found in the eel mucus ointment group any more (Figure 5).

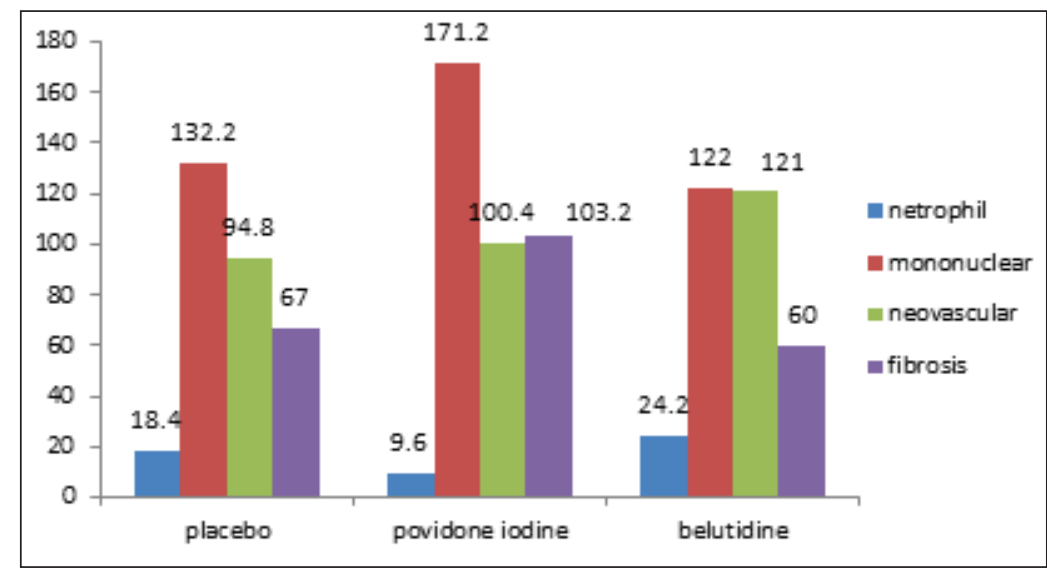

Fig. 3. Mean of Neutrophil, Mono-nuclear Cells, Neo-vascular Cells, and Fibrosis of Day 6.

Tabel 3: Mean of Histopathologic Data of Wounds Day 9

\begin{tabular}{|c|c|c|c|c|c|c|c|c|}
\hline \multirow{3}{*}{$\begin{array}{l}\text { Groups (N samples } \\
\text { evaluated on day 9) }\end{array}$} & \multicolumn{8}{|c|}{ Mean } \\
\hline & \multicolumn{2}{|c|}{ Neutrophil } & \multicolumn{2}{|c|}{ Mononuclear } & \multicolumn{2}{|c|}{ Neo-vascular } & \multicolumn{2}{|c|}{ Fibrosis } \\
\hline & Mean & SD & Mean & SD & Mean & SD & Mean & SD \\
\hline $\begin{array}{l}\text { Placebo (Vaseline } \\
\text { ointment) }(\mathrm{N}=5)\end{array}$ & 0 & 0 & 78 & 70.9 & 64.4 & 61 & 150 & 103.3 \\
\hline Povidone iodine $(\mathrm{N}=5)$ & 12.8 & 26.9 & 185.6 & 85.6 & 110.2 & 61.5 & 158 & 38.7 \\
\hline $\begin{array}{l}\text { Eel mucus ointment } \\
\text { (Belutidine) }(\mathrm{N}=5)\end{array}$ & 1.2 & 2.6 & 114.6 & 29.4 & 185.2 & 99.8 & 301.4 & 58.4 \\
\hline Kruskal wallis test & 0.041 & & 0.180 & & 0.10 & & 0.00 & \\
\hline
\end{tabular}

* Different significantly based on Kruskal Wallis test 


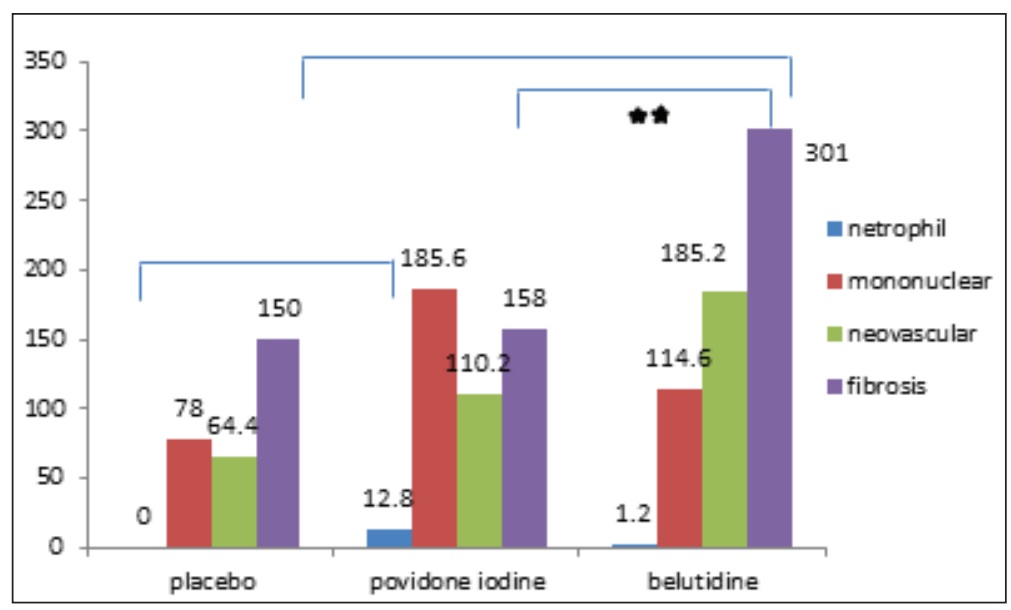

Fig. 4. Mean of Neutrophil, Mono-nuclear cells, Neo-vascular cells, and Fibrosis of day 9. ${ }^{* *} \mathrm{p}<0.05$ (significantly different based on Mann Whitney test).

\section{Discussion}

This study examines the effectiveness of eel mucus ointment "Belutidine" on the healing of wounds. It was evaluated by macroscopic and microscopic observations of the scar on the $3^{\text {rd }}$ day, the $6^{\text {th }}$ and $9^{\text {th }}$ days of treatment. Serial data observation is very important to explain the progress of certain types of wound healing.

Wound healing, also called tissue recovery is strongly influenced by several factors, including inflammatory cells, epithelial cells, extra cell matrix, Angiogenesis and others. In general, wound healing is divided into two types according to the characteristics and the healing phases namely primary and secondary wound healing. Primary wound healing has a major mechanism of epithelial regeneration. In the first
24 hours of primary wound healing, neutrophils can be widely encountered, and then epithelial cells begin to migrate and proliferated along the dermis. On the $3^{\text {rd }}$ day, neutrophils will be replaced by macrophages and granulation tissues fill in the initiation. Subsequent to the $5^{\text {th }}$ day of complete neovascularization, collagen fibers begin to be encountered on the edges of the incision to connect both ends. After that the thickness of the epidermis begins to return to normal and form keratin on the surface ${ }^{14,15}$.

In contrast to primary healing, secondary healing is a more complex mechanism because it is a combination of epithelial regeneration and scar tissue formation. This type of healing is characterized by a more intense inflammatory phase, extensive granulation tissue and also extensive ECM accumulation and scarring. On the

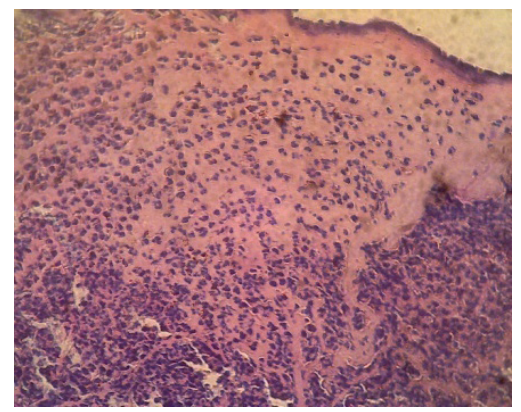

A

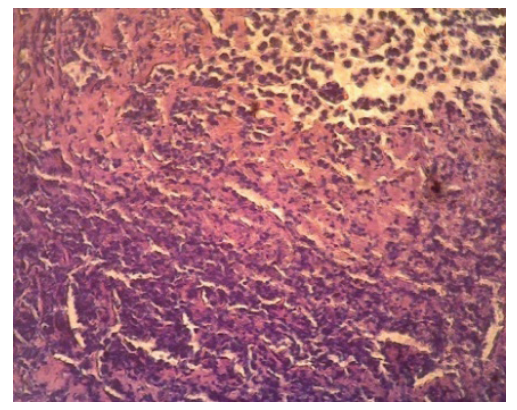

B

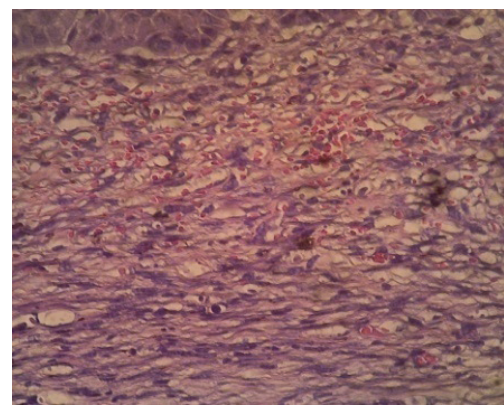

C

Fig. 5. Histopathological image of: A. Placebo group. B. Povidone lodine. C. Eel Mucus Ointment Groups. 
secondary healing, blood clot and traces of connective tissue remain on the surface of the wound and usually occur in large cuts ${ }^{14}$.

In this study, the test was performed on 3 groups; Group I was treated with placebo (ointment without active ingredients), group II was the control group treated with povidone iodine ointment, and group III was the treatment group. After observation, it was found that wound healing in group I was primary healing while group II and group III tended to be secondary healing. This can be seen from the data of the length of the wound and the number of cells that have been observed previously. The average length of group I scar is the widest among all the groups and group III has the shortest length of wound. This is understandable because one of the consequences of secondary healing is the wound contraction due to the high connective tissue that is formed ${ }^{14}$. With the contraction of the wound, the length of the scar on secondary healing can be reduced by $5-10 \%$. In addition, the remaining mounds of scar tissue on the wound surface are found only in group II and group III which were characteristic of secondary healing.

\subsection{Application of Vaseline Ointment Base on the Wound (Group I)}

The Vaseline ointment base used for treating group I did not contain any specific active ingredients that can improve healing process or prevent wound infections. Vaseline is commonly used for treating wound, particularly if the wound bed has little exudate or is dry. The application of sterile Vaseline permeated gauze maintains a moist wound surface to facilitate healing. ${ }^{16,17}$ In this study, essential Vaseline album used for ointment only served to moisturize the surface of the skin while Adeps played its role to absorb the liquid. However, since it does not contain any active ingredient, the restoration of tissue in the wound that was only given the base of the ointment was not disrupted so that the healing phases such as inflammation, re-epithelization and connective tissue formation can be processed naturally to recover itself, as long as there is no infection of the wound. Thus, the injury in the treatment group I remained significantly improved and deteriorated on the $3^{\text {rd }}$ and $6^{\text {th }}$ days due to its primary healing.

\subsection{Treatment of Wound with Povidone lodine (Group II)}

Betadine which is used for treatment for group II contains a $10 \%$ povidone iodine which is widely used as an antiseptic in cases of minor injuries as well as large wounds, such as in surgery. The main advantage of povidone iodine is as an antiseptic to prevent wounds from various bacteria. Povidone iodine can oxidize bacterial respiration enzymes and iodinate amino acids bacteria. However, povidone iodine may cause irritating, toxic, skin-induced skin effects and skin discoloration. Povidone iodine may also inhibit fibroplasia in cell culture in vitro ${ }^{3}$. This is in line with the results of this study, which, on the $9^{\text {th }}$ day, in the proliferative phase, the wound given betadine has the least average number of fibrosis.

\subsection{Treatment of Wound with Eel Mucus Ointment (Belutidine)}

Eel mucus contains lysozyme and glycoprotein which can serve as an antimicrobial agent for wound healing process and protect the wound free from infection. In addition, glycoprotein is one of the main components of ECM (extra cellular matrix). There is no doubt that ECM has a very fundamental role in wound healing. The wound healing phases are divided into hemostatic phases, inflammation, proliferation and granulation. Among these phases, ECM plays an important role in the proliferation phase ${ }^{18}$.

In the process of proliferation, the first to occur is massive ECM production. An extra cellular or ECM matrix is needed because it serves to make room for important components such as blood vessels, epithelium, and fibroses to grow, and replace damaged tissue. In addition, ECM also serves to provide a microenvironment in which ECM can contain various growth factors such as TGF- $\alpha$, TGF $\beta$, KDAF produced by keratinocyte cells; IGF-1, bFGF, TGF- $\beta$, PDGF, and EGF produced by fibroblasts; VEGF, bFGF, and PDGF produced by endothelial cells in which the abovementioned mediators act for a) angiogenesis b) ECM biosynthesis and c) epithelization. Giving syrup ointment is expected to help the ECM biosynthesis process ${ }^{18}$. 
Furthermore, ECM components are also very important for the activation of fibroblasts into fibrosis that play a role in the formation of granulation tissue and scar tissue ${ }^{18}$. Presumably there are components on the active ingredient of eel mucous ointment that can increase the activation of fibroblasts into fibrosis so that the formation of scar tissue and granulation is large (the hallmark of secondary healing). The wound healing effect can be inferred from the $9^{\text {th }}$ day treatment fibrosis data. It can be seen that the treatment group (group III, treated with eel mucous ointment) has the highest mean score of fibrosis compared to that of povidone iodine and placebo groups. The neutrophil of Group III on $9^{\text {th }}$ day also reached zero which means the inflammatory process is over completely.

The effect of wound healing by eel mucous ointment is not particularly noticeable on the $3^{\text {rd }}$ and $6^{\text {th }}$ days compared to group I and group II. Even so, group III observations indicated consistent findings Neutrophils are high on $3^{\text {rd }}$ day because they are still in the inflammatory stage, and then gradually decreased to 0 day on the $9^{\text {th }}$ day of treatment. The decrease in the number of neutrophils was followed by an increase in the number of mononuclear cells or macrophages, neovascular and fibrosis from $3^{\text {rd }}$ day to $9^{\text {th }}$ day. These results clearly illustrate the phases of secondary wound healing.

\section{Conclusion}

Considering the results, observation and data analysis in this study, it could be concluded that the eel mucus ointment (Belutidine) effectively heal the wound, as marked by the high amount of fibrosis and shortest scar length on $9^{\text {th }}$ day of treatment.

\section{Acknowledgements}

The authors wish to thank the Directorate General of Higher Education, Ministry of Research, Technology and Higher Education, Republic of Indonesia, for funding the project; Dr. Susilorini, Sp.PA for helping to observe the histopathologic data and all officers and workers at Animal Laboratory of Biology Department, Faculty of Medicine, Universitas Islam Sultan Agung.

\section{Funding}

This project was funded by the Ministry of Research, Technology and Higher Education of Indonesia, under the scheme of Program Kreatifitas Mahasiswa.

\section{Consent to Publish}

Not applicable.

\section{Competing Interests}

The authors declare that they have no competing interests. The authors alone are responsible for the writing and content of this paper.

\section{Authors' Contributions}

All authors designed the study and the steps of treatment and data collection. MTA, MFA, SPRW performed the studies, analyzed the data and drafted the manuscript. EL and RW contributed to the study's conception and helped analyzing the data and drafting the manuscript. All authors reviewed and approved the final manuscript.

\section{References}

1. Hashemi SA, Madani SA, Abediankenari S. The review on properties of Aloe vera in healing of cutaneous wounds. BioMed Research International. 2015; 1-6. Crossref. PMid:26090436 PMCid:PMC4452276

2. Ministry of Health Republic Indonesia. Report on Basic Health Studies (RISKESDAS). 2013.

3. Rahmawati I. The different effects of wound care using Leucaena glauce benth and povidone iodine 10\% in accelerating wound healing in Cavia pocellus. J Wiyata. 2014; 1:227-34.

4. Serafini MR, Guimaraes AG, Quintans-Junior LG, Nunes PS, Matos IG, Sravanan S, De Souza AAA. Recent patents on medicinal plants/natural products as a therapeutic approach to wounds and burns healing. Recent Pat Biotechnol. 2014;8:231-9. Crossref. PMid:27099146 
5. Andrade PHM, Schmidt R E, Carollo CA, Rodrigues MML, Viana LH, De Souza SA, et al. Effect of powdered shells of the snail Megalobulimus lopesi on secondaryintention wound healing in an animal model. Evidencebased Complement Altern Med. 2015; 1-9.

6. Builders PF, Kabele-Toge B, Builders M, Chindo B, Anwunobi $\mathrm{P}$, and Isimi Y. Wound healing potential of formulated extract from hibiscus sabdariffa calyx. Indian Journal of Pharmaceutical Sciences. 2013; 75(1):45-52. Crossref. PMid:23901160 PMCid:PMC3719149

7. Hajiaghaalipour F, Kanthimathi MS, Abdulla MA, and Sanusi J, The effect of camellia sinensis on wound healing potential in ananimal model. Evidence-Based Complementary and Alternative Medicine. 2013; 1-7. Crossref. PMid:23864889 PMCid:PMC3705756

8. Mulyani D, Febriyenti F, Almahdy A. The Effect of Monopterus albus extract on burns of Sprague-Dawley White Rats. Journal Sains Farmasi and Klinis, 2016; 2(2):191-4. Crossref.

9. Kumar S, Ghosh D, Biswas TK, Dutta U, Das P, Kundu S. Spermatheca gland extract of snail (Telescopium telescopium) has wound healing potential: an experimental study in rabbits. International Journal of Low Extrem Wounds. 2008; 7(4):204-9. Crossref. PMid:19019846

10. Harmon C, Hawkins J, Li J, Connell C, Miller M, Saenger $\mathrm{M}$, et al. Effects of topical application of silver sulfadiazine cream, triple antimicrobial ointment, or hyperosmolar nanoemulsion on wound healing, bacterial load, and exuberant granulation tissue formation in bandaged fullthickness equine skin wounds. Am J Vet Res. 2017 May; 78(5):638-46.
11. Liang $\mathrm{Y}$, Guan R, Huang $\mathrm{W}, \mathrm{Xu}$ T. Isolation and identification of a novel inducible antibacterial peptide from the skin mucus of Japanese Eel, Anguilla japonica. Protein Journal. 2011; 30:413-21. Crossref. PMid:21796440

12. Divadi A, Yuliani S. Preparation and effectiveness test of scare-less wound gel of Anredera cordifolia extract and piroxicam. J Farm sains dan komunitas. 2015; 12(2):41-7.

13. Adibhesami M, Ahmadi M, Farshid AA, Sarrafzadehrezaei F, Dalir-naghadeh B. Effects of silver nanoparticles on Staphylococcus aureus contaminated open wounds healing in mice: An experimental study. Vet Res Forum. 2017; 8(1):23-8. PMid:28473893 PMCid:PMC5413307

14. Kumar V, Cotran R., Robbins SL. Robbins Basic Patholoy. 10th ed. Elsevier Inc. 2017. p.75-82.

15. Pastar I, Stojadinovic O, Yin NC, Ramirez H, Nusbaum AG, Sawaya A, et al. Epithelialization in Wound Healing: A Comprehensive Review. Advanced Wound Care 2014;3(7):445-64. Crossref. PMid:25032064 PMCid: PMC 4086220

16. Huang S, Lin $\mathrm{CH}$, Chang $\mathrm{KP}$, et al. Clinical Evaluation Comparing the Efficacy of Aquacel Ag with Vaseline Gauze versus $1 \%$ Silver Sulfadiazine Cream in Toxic Epidermal Necrolysis. Advances in Skin and Wound Care. 2014; 27(5):210-15. Crossref. PMid:24732124

17. Delay C, Cameron Journal of Wound Management. Oxfford: Wiley Blackwell; 2008. p.104.

18. Olczyk P, Mencner A, Vasse KK. The Role of the Extracellular Matrix Components in Cutaneous Wound Healing. Hindawi Publ Corp BioMed Res Int. 2014;1-7. 